\title{
Clinical Significance of Immunoglobulin E Responses to Staphylococcal Superantigens in Patients with Aspirin-Exacerbated Respiratory Disease
}

\author{
Hye-Soo Yoo Yoo-Seob Shin Jing Nan Liu Mi-Ae Kim Hae-Sim Park \\ Department of Allergy and Clinical Immunology, Ajou University School of Medicine, Suwon, South Korea
}

\begin{abstract}
Key Words
Staphylococcal enterotoxins · Superantigens .

Immunoglobulin E. Aspirin-exacerbated respiratory

disease $\cdot$ Asthma
\end{abstract}

\begin{abstract}
Background: Previous studies have reported a higher prevalence of immunoglobulin E (IgE) specific for staphylococcal superantigens $(\mathrm{SAg})$ in the nasal mucosa of patients with aspirin-exacerbated respiratory disease (AERD), associated with eosinophilic inflammation and leukotriene production. However, the role of SAg-specific lgE in the pathogenesis of AERD is not well understood. We evaluated the clinical significance of serum IgE specific for three types of $S A g$, namely staphylococcal enterotoxins A and B (SEA and SEB) and toxic shock syndrome toxin-1 (TSST-1) in AERD. Methods: We enrolled 147 patients with AERD confirmed by a lysineacetyl salicylic acid bronchoprovocative test and compared them with 147 patients with aspirin-tolerant asthma (ATA) and 141 healthy controls (NC). The levels of serum total IgE and SAg-specific IgE were measured using an ImmunoCAP system. Other clinical parameters were analyzed retrospectively. Results: The prevalences of SEA-, SEB- and TSST1 -specific lgE in the AERD and ATA groups were significantly higher than those in the NC group ( $p<0.05$, respectively). The total IgE level was significantly higher in patients with
\end{abstract}

\section{KARGER}

(c) 2013 S. Karger AG, Base

$1018-2438 / 13 / 1624-0340 \$ 38.00 / 0$

E-Mail karger@karger.com

www.karger.com/iaa
AERD with high levels of SEA-specific IgE than in those with lower levels $(p<0.05)$, with significant positive correlations between total and SAE-specific lgE levels $(p<0.05)$. The $P C_{20}$ methacholine level was significantly lower in patients with AERD with high levels of SEA-specific lgE, while a significantly higher eosinophil count was noted in patients with AERD with high levels of SEB-specific IgE ( $p<0.05$, respectively). Conclusions: Specific IgE responses to $S A g$ may increase the serum total IgE level, airway hyperresponsiveness and eosinophil activation, leading to more severe clinical symptoms in AERD.

(c) 2013 S. Karger AG, Basel

\section{Introduction}

Superantigens, predominantly derived from Staphylococcus aureus, have been recognized that may be linked to T-helper type 2 (Th2) cell-mediated inflammation and directly affect the activities of inflammatory leukocytes, such as mast cells and eosinophils [1-4]. Staphylococcal superantigens (SAg) have recently been implicated in the pathogenesis of various allergic conditions, e.g. atopic dermatitis, urticaria, allergic rhinitis, nasal polyposis and bronchial asthma [5-8]. Previous studies have reported that the prevalence of serum-specific immunoglobulin $\mathrm{E}$ (IgE) to SAg is related to the severity of asthma and eo- 
Table 1. Clinical characteristics of the study subjects

\begin{tabular}{|c|c|c|c|c|c|c|}
\hline & $\begin{array}{l}\text { AERD } \\
(\mathrm{n}=147)\end{array}$ & $\begin{array}{l}\text { ATA } \\
(\mathrm{n}=147)\end{array}$ & $\begin{array}{l}\text { NC } \\
(n=141)\end{array}$ & \multicolumn{3}{|l|}{$\mathrm{p}$ value* } \\
\hline Gender, female & $96(65.3)$ & $88(59.9)$ & $91(64.5)$ & 0.399 & 0.902 & 0.466 \\
\hline Atopy & $61 / 139(43.88)$ & $60 / 101(59.41)$ & 0 & 0.018 & $<0.001$ & $<0.001$ \\
\hline Severe asthma & $27 / 108$ & $15 / 87$ & NA & 0.190 & NA & NA \\
\hline Log (total IgE), kU/l & $5.1 \pm 1.2$ & $5.1 \pm 1.5$ & NA & 0.897 & NA & NA \\
\hline $\mathrm{TEC}, \times 10^{3} / \mu \mathrm{l}$ & $432.3 \pm 341.7$ & $449.6 \pm 691.8$ & NA & 0.817 & NA & NA \\
\hline Sputum eosinophil, \% & $32.49 \pm 36.93$ & $23.54 \pm 32.04$ & NA & 0.313 & NA & NA \\
\hline $\mathrm{FEV}_{1}, \%$ & $86.99 \pm 18.51$ & $86.90 \pm 20.87$ & NA & 0.975 & NA & NA \\
\hline $\mathrm{PC}_{20}$ methacholine, $\mathrm{mg} / \mathrm{ml}$ & $3.49 \pm 6.73$ & $6.63 \pm 8.83$ & NA & 0.011 & NA & NA \\
\hline
\end{tabular}

Data are presented as means \pm standard deviation (SD). Figures in parentheses are percentages. $p$ values were determined using the Pearson $\chi^{2}$ test for categorical variables and the Student $t$ test for continuous variables. Values in bold type indicate a significant $\mathrm{p}$ value. $\mathrm{NA}=$ Not applicable; TEC $=$ total eosinophil count.

sinophilic inflammation in adult asthma [9-11]. In addition, a few reports have demonstrated the presence or increased level of specific IgE to SAg in nasal polyp tissue of patients with aspirin-exacerbated respiratory disease (AERD). However, the presence of serum-specific IgE to SAg and its clinical relevance in patients with AERD has been reported only rarely [12-15]. Considering that chronic eosinophilic inflammation is a key feature of upper and lower airway inflammation in AERD, we hypothesized that SAg might be relevant to eosinophilic airway inflammation in patients with AERD [16]. Therefore, we evaluated serum IgE sensitization to three types of SAg, including staphylococcal enterotoxins A and B (SEA and SEB) and toxic shock syndrome toxin-1 (TSST-1), in association with the clinical features in patients with AERD.

\section{Material and Methods}

This study included 147 patients with AERD, 147 patients with aspirin-tolerant asthma (ATA) and 141 nonatopic healthy controls (NC) from Ajou University Hospital, Suwon, South Korea. The diagnosis of asthma in all patients was based on the International Global Initiative for Asthma guidelines. AERD was diagnosed by a positive response to a lysine-acetyl salicylic acid bronchoprovocative test, which was performed according to a method described previously [17]. The NC group was recruited using a screening questionnaire from a general population with no medical history, including drug allergy and respiratory symptoms. A skin prick test to common inhalant allergens (Bencard, Bradford, UK) was performed. Atopy was defined if the skin prick test showed one or more positive responses to allergens. The levels of total IgE and specific IgE to SEA, SEB and TSST-1 were measured using the ImmunoCAP system (Phadia, Valinge, Sweden). The cut-off value for a positive result for a specific IgE was $0.35 \mathrm{kU} / \mathrm{l}$ as recommended by the manufacturer. The presence of chronic rhinosinusitis (CRS) and nasal polyps was checked using paranasal sinus X-ray and rhinoscopy. Methacholine bronchial challenge tests were performed as described previously [18]. Severe asthma was diagnosed according to the definition of the American Thoracic Society Workshop 2000 [19]. This study was approved by the institutional review board of Ajou University Hospital and performed with the written informed consent of all participants.

All data are presented as means \pm standard deviation (SD). For analysis, total IgE values were transformed logarithmically and are presented as geometric means. Group comparisons with continuous (binary) variables were performed using the Kruskal-Wallis (Fisher's exact) test. To evaluate the statistical significance of the correlation between two variables, specific IgE to SAg, and other asthma-related clinical parameters, the Pearson correlation analysis was applied (SPSS 16.0 Inc., Chicago, Ill., USA).

\section{Results}

The clinical characteristics of the study subjects are detailed in table 1. The AERD and ATA groups were not significantly different in terms of age, gender and comorbidities with severe asthma. The mean ages of patients with AERD and ATA were significantly higher than those of the NC group $(46.7 \pm 13.5$ and $42.6 \pm 13.4$ years vs. $31.9 \pm 10.9$, respectively; $\mathrm{p}<0.001)$. The 2 asthma groups (AERD vs. ATA) showed no significant differences in the mean levels of total $\operatorname{IgE}$ and other clinical parameters, such as the total eosinophil count, eosinophil cationic 


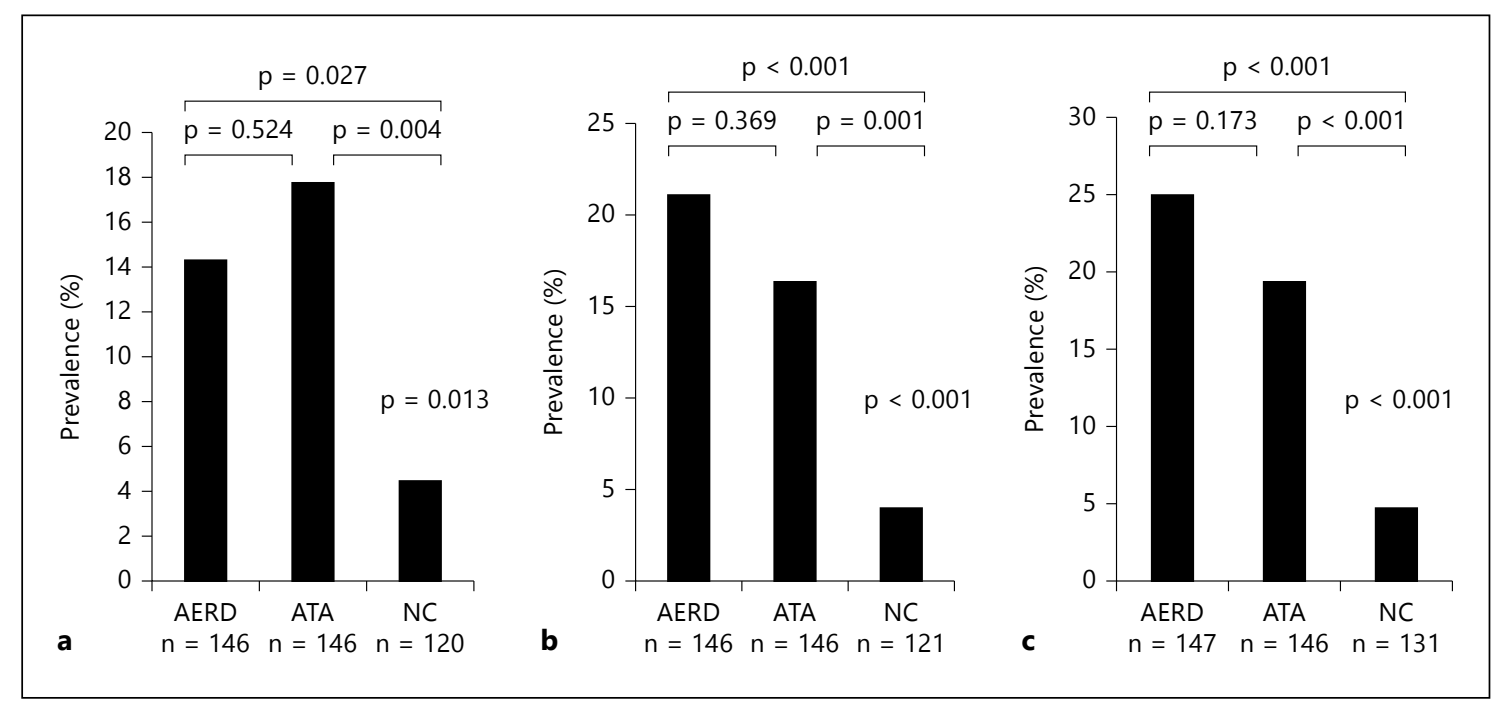

Fig. 1. The prevalence of serum specific IgE to three types of SAg including SEA (a), SEB (b) and TSST-1(c) in patients with AERD, ATA and in NC.

protein (ECP), sputum eosinophil percentage, and predicted value of forced expiratory volume in $1 \mathrm{~s}\left(\mathrm{FEV}_{1} \%\right)$. The mean value of $\mathrm{PC}_{20}$ methacholine in patients with AERD was significantly lower than that in patients with ATA $(3.49 \pm 6.73$ vs. $6.63 \pm 8.83 \mathrm{mg} / \mathrm{ml} ; \mathrm{p}<0.001)$. The atopy rate was significantly higher in patients with ATA than in those with AERD ( $p=0.018)$. The comorbidities of CRS and nasal polyps were significantly higher in patients with AERD than in those with ATA ( $p=0.005$ and $\mathrm{p}<0.001$, respectively).

The prevalence and level of serum IgE specific for each SAg were compared among the 3 groups. The prevalences of serum SEA-, SEB- and TSST-1-specific IgE in the AERD and ATA groups were significantly higher than in the NC group ( $\mathrm{p}<0.05$; fig. 1 ). The prevalence of specific IgE to SEB tended to be higher in the AERD than in the ATA group (21.2 vs. $16.4 \%)$, but statistical significance was not reached.

Asthma-related clinical parameters were compared according to positivity for IgE specific for each SAg in patients with AERD (table 2). The correlations between clinical parameters and SAg-specific IgE were assessed in patients with AERD using the Pearson correlation. No significant differences were noted in the mean age, atopy rate, severe asthma, CRS, nasal polyps, sputum eosinophil percentage and $\mathrm{FEV}_{1} \%$ when patients with AERD were stratified according to the presence of SAg-specific IgE. However, the serum total IgE level was significantly higher in patients with AERD with a positive IgE specific for each SAg than in those who were negative $(\mathrm{p}<0.05)$, with significant positive correlations between the mean levels of total IgE and IgE specific for each SAg $(r=0.230$ for SEA, $r=0.234$ for SEB and $r=0.226$ for TSST $-1 ; \mathrm{p}<0.05$ ). The $\mathrm{PC}_{20}$ methacholine level was significantly lower in patients with AERD positive for SEA-specific IgE, while the total eosinophil count was significantly higher in patients with AERD positive for SEB-specific IgE than in those who were negative.

\section{Discussion}

Superantigens are virulent polypeptides that are produced by a variety of infectious organisms. Among them, S. aureus-derived enterotoxins are known to possess potent stimulatory effects on T cells, eosinophils, neutrophils and other inflammatory cells involved in asthmatic inflammation, although $S$. aureus is often found as a part of the normal microflora of the upper airway $[1,20,21]$. The exotoxins of $S$. aureus were detected more frequently in patients with CRS than in the NC. Furthermore, the mean eosinophil counts tended to be higher in exotoxinpositive patients with CRS than in those without CRS [22]. SEA seems to induce proasthmatic, T-cell-mediated changes in the airway smooth muscle when presented by airway smooth muscle to CD4+ lymphocytes [23]. In animal studies, SEB was shown to trigger the recruitment of proinflammatory cells and the production of several cytokines associated with airway responsiveness [24]. More recently, SEB has been demonstrated to induce release of 
Table 2. The comparison of clinical parameters according to positivity for specific IgE to each staphylococcal superantigen in patients with AERD

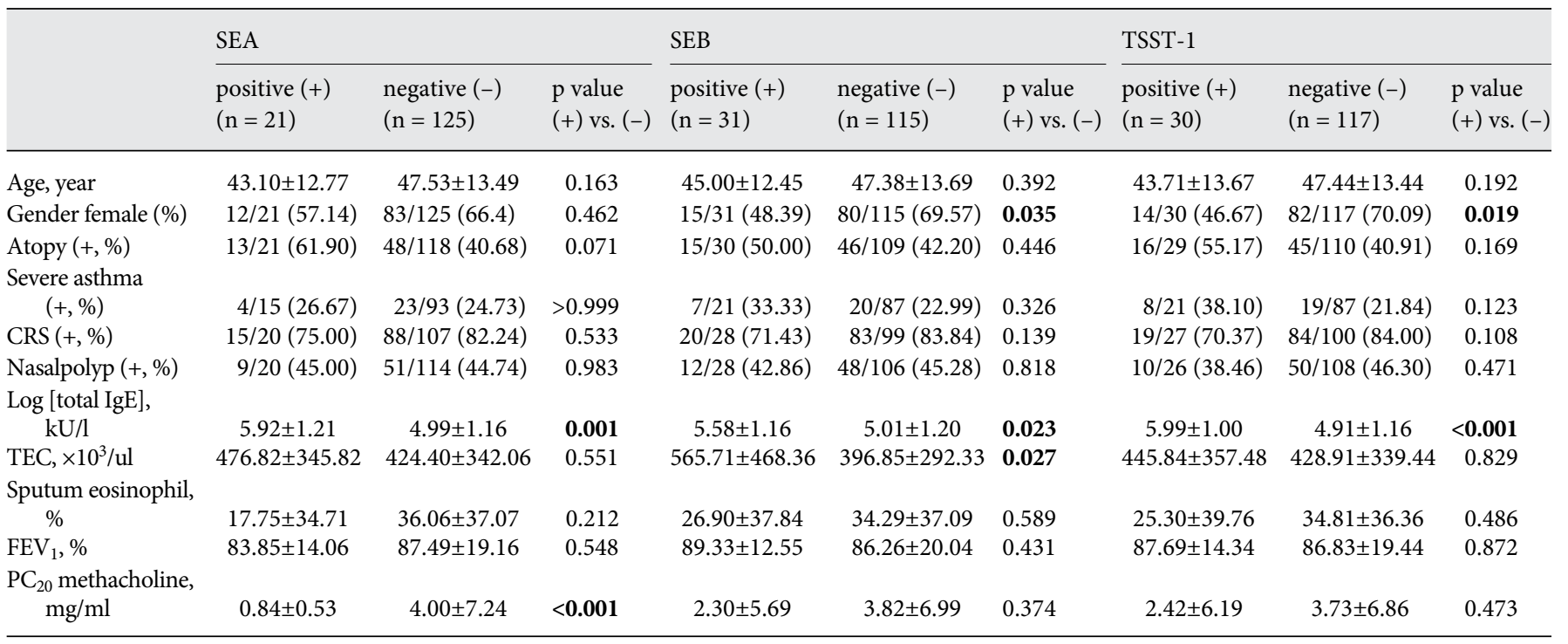

Data are presented as means \pm standard deviation (SD). $\mathrm{p}$ values were determined using Pearson's $\chi^{2}$ test for categorical variables and the $t$ test for continuous variables. Values in bold indicated a significant $\mathrm{p}$ value. AERD $=$ Aspirin-exacerbated respiratory disease; TSST-1 = toxic shock syndrome toxin-1; SEA = staphylococcal enterotoxin $\mathrm{A} ; \mathrm{SEB}=$ staphylococcal enterotoxin $\mathrm{B} ;+=$ presence; $-=$ absence; $\mathrm{CRS}=$ chronic rhinosinusitis; $\mathrm{D} 1=$ Dermatophagoides pteronyssinus; $\mathrm{D} 2$ = Dermatophagoides farina $; \mathrm{TEC}=$ total eosinophil count; $\mathrm{FEV}_{1}=$ forced expiratory volume.

Th2-type cytokines while disfavoring T-regulatory cytokine release in nasal polyp tissue [25]. Furthermore, there are data demonstrating that SEB facilitates sensitization to ovalbumin and consecutive bronchial inflammation with the airway hyperresponsiveness of an allergic asthma phenotype in mouse models [26]. The colonization rate of $S$. aureus in nasal tissue homogenates was higher in asthmatic patients with aspirin sensitivity along with an increased level of ECP. These studies suggest that local SAg may promote Th2 and eosinophilic inflammation in the upper and lower airways of patients with asthma and rhinitis. This increasing amount of evidence also suggests the involvement of SAg in chronic eosinophilic inflammation in the upper and lower airway mucosa of patients with AERD.

Superantigen-induced immune responses mediated by IgE have also been reported in airway disease. IgE antibodies to SAg have been described in nasal polyp tissue and linked to local polyclonal IgE production and eosinophilic inflammation, which is often associated with severe asthma and aspirin hypersensitivity [13, 14,27]. More recently, a study identified that serum SAg-specific IgE antibodies are risk factors for asthma, particularly severe asthma, although the presence of specific IgE to grass pollen or house-dust mite allergen was not an independent risk factor for asthma or asthma severity [11]. Previous studies reported that the production of tissue eicosanoid, cysteinyl leukotrienes (LT), LT B4 and lipoxin A4 was increased in patients with nasal polyps with high levels of IgE specific for SAg compared to those without SAgspecifc IgE; this eicosanoid concentration was correlated with IL-5 and ECP levels [28]. In this study, the prevalence and levels of serum IgE specific for three SAgs in patients with AERD were significantly higher than in the NC. However, no significant differences were noted in the serum SAg-specific IgE response compared to that in patients with ATA, which is in contrast to previous reports that the prevalence of local SAg-specific IgE within nasal polyp tissue was significantly higher in patients with AERD than in those with ATA [13-15]. These findings suggest that the local IgE response to SAg in target tissues of patients with AERD may increase airway inflammation. Further studies should investigate the effect of a local SAg-specific IgE response in patients with AERD compared with systemic specific IgE responses.

This study strengthens and extends the findings of previous reports of a strong relationship between serum SAgspecific IgE and total IgE levels [9, 10, 29]. When patients with AERD were stratified according to the presence or absence of serum SEA-, SEB- and TSST-1-specific IgE, 
each subgroup that had a high level of IgE specific for the three SAgs showed significantly higher serum total IgE levels than did those without IgE specific for each SAg (table 2). No significant difference in the presence of atopy was noted between the 2 groups. These findings may explain why some patients with AERD who were classified as nonatopic because they showed negative results on the skin prick test but had high total serum IgE levels, were found to have high levels of serum SAg-specific IgE [30]. Therefore, SAg may increase the serum total IgE level by stimulating IgE production by B cells, regardless of the atopic status of the patient. Another notable outcome of this study is the $\mathrm{PC}_{20}$ methacholine level being significantly lower in patients with AERD with high levels of SEAspecific IgE compared to those with lower levels. A significant negative correlation between the levels of SEAspecific IgE and $\mathrm{PC}_{20}$ methacholine was found. These data are in agreement with those of other studies, supporting the notion that SAg contributes to increased airway hyperresponsiveness in asthmatic patients [12,23]. In addition, the peripheral eosinophil count was significantly increased in patients with AERD with high specific IgE to SEB. A notable effect of immune responses to SAg on the eosinophilic inflammation in nasal polyp tissue has been reported [27, 28]. Huvenne et al. [31] reported that SEB induced human nasal epithelial cells to upregulate proinflammatory mediators, resulting in prolonged survival of eosinophilic granulocytes and contributing to airway remodeling. SAg can stimulate IL-5 production, which may induce the activation of 5-lipoxygenase, leading to LT synthesis and subsequent recruitment of activated eosinophils to the site of inflammation [30,32]. Likewise, our previous study demonstrated that the SEB-specific IgE titer in nasal polyp tissue was significantly higher in patients with AERD than in those with ATA, with significant positive correlations between the levels of specific IgE to SEB and ECP or IL-5 [13]. These findings suggest that a SAgspecific IgE response is implicated in eosinophilic airway inflammation in patients with AERD. Our data suggest that a specific IgE response to the three types of SAg could increase the serum total IgE level in patients with AERD. In addition, a SEA-specific IgE response may contribute to increased airway hyperresponsiveness, while a SEBspecific IgE response could contribute to increased peripheral eosinophil counts. Previous studies have reported that HLA allele DPB $1^{*} 0301$ is a strong marker for AERD because patients with this allele presented with an AERD phenotype, such as a decreased $\mathrm{FEV}_{1} \%$ and high comorbidity of CRS with nasal polyps [33-35]. In this study, no significant association between IgE sensitization to SEAs and the HLA-DBP*0301 allele was found.

In conclusion, we suggest a role for SAg-specific IgE in modifying the severity of airway inflammation, leading to more severe clinical symptoms in patients with AERD. Further studies are needed to clarify the details of the mechanism underlying the difference in the effect of SAg in upper and lower airway inflammation in patients with AERD compared with those with ATA.

\section{Acknowledgement}

This study was supported by grants from the Korean Health 21 R\&D project, Ministry of Health and Welfare, ROK (A111218-11PG01).

\section{References}

$>1$ Kotzin BL, Leung DY, Kappler J, Marrack P: Superantigens and their potential role in human disease. Adv Immunol 1993;54:99_ 166.

-2 Domiati-Saad R, Lipsky PE: B cell superantigens: potential modifiers of the normal human B cell repertoire. Int Rev Immunol 1997; 14:309-324.

3 Macias ES, Pereira FA, Rietkerk W, Safai B: Superantigens in dermatology. J Am Acad Dermatol 2011;64:455-472; quiz 474.

4 Wehner J, Neuber K: Staphylococcus aureus enterotoxins induce histamine and leukotriene release in patients with atopic eczema. $\mathrm{Br}$ J Dermatol 2001;145:302-305.

5 Baker BS: The role of microorganisms in atopic dermatitis. Clin Exp Immunol 2006; 144:1-9.
-6 Ye YM, Hur GY, Park HJ, Kim SH, Kim HM, Park HS: Association of specific IgE to staphylococcal superantigens with the phenotype of chronic urticaria. J Korean Med Sci 2008; 23:845-851.

7 Pastacaldi C, Lewis P, Howarth P: Staphylococci and staphylococcal superantigens in asthma and rhinitis: a systematic review and meta-analysis. Allergy 2011;66:549-555.

8 Zhang N, Holtappels G, Gevaert P, Patou J, Dhaliwal B, Gould H, Bachert C: Mucosal tissue polyclonal IgE is functional in response to allergen and SEB. Allergy 2011;66: 141-148.

-9 Kowalski ML, Cieslak M, Perez-Novo CA, Makowska JS, Bachert C: Clinical and immunological determinants of severe/refractory asthma (SRA): association with Staphylococ- cal superantigen-specific IgE antibodies. Allergy 2011;66:32-38.

10 Bachert C, Gevaert P, Howarth P, Holtappels $G$, van Cauwenberge P, Johansson SG: IgE to Staphylococcus aureus enterotoxins in serum is related to severity of asthma. J Allergy Clin Immunol 2003;111:1131-1132.

11 Bachert C, van Steen K, Zhang N, Holtappels G, Cattaert T, Maus B, Buhl R, Taube C, Korn S, Kowalski M, Bousquet J, Howarth P: Specific IgE against Staphylococcus aureus enterotoxins: an independent risk factor for asthma. J Allergy Clin Immunol 2012;130:376-381.e378.

12 Lee JY, Kim HM, Ye YM, Bahn JW, Suh CH, Nahm D, Lee HR, Park HS: Role of staphylococcal superantigen-specific IgE antibodies in aspirin-intolerant asthma. Allergy Asthma Proc 2006;27:341-346. 
-13 Suh YJ, Yoon SH, Sampson AP, Kim HJ, Kim $\mathrm{SH}, \mathrm{Nahm}$ DH, Suh CH, Park HS: Specific immunoglobulin $\mathrm{E}$ for staphylococcal enterotoxins in nasal polyps from patients with aspirin-intolerant asthma. Clin Exp Allergy 2004;34:1270-1275.

14 Van Zele T, Gevaert P, Watelet JB, Claeys G, Holtappels G, Claeys C, van Cauwenberge P, Bachert C: Staphylococcus aureus colonization and IgE antibody formation to enterotoxins is increased in nasal polyposis. J Allergy Clin Immunol 2004;114:981-983.

15 Perez-Novo CA, Kowalski ML, Kuna P, Ptasinska A, Holtappels G, van Cauwenberge P, Gevaert P, Johannson S, Bachert C: Aspirin sensitivity and IgE antibodies to Staphylococcus aureus enterotoxins in nasal polyposis: studies on the relationship. Int Arch Allergy Immunol 2004;133:255-260.

16 Palikhe NS, Kim SH, Kim JH, Losol P, Ye YM, Park HS: Role of Toll-like receptor 3 variants in aspirin-exacerbated respiratory disease. Allergy Asthma Immunol Res 2011;3:123127.

17 Palikhe NS, Kim SH, Cho BY, Choi GS, Kim $\mathrm{JH}$, Ye YM, Park HS: IL-13 gene polymorphisms are associated with rhinosinusitis and eosinophilic inflammation in aspirin-intolerant asthma. Allergy Asthma Immunol Res 2010;2:134-140.

-18 Kim SH, Bae JS, Holloway JW, Lee JT, Suh $\mathrm{CH}, \mathrm{Nahm} \mathrm{DH}$, Park HS: A polymorphism of MS4A2 (-109T > C) encoding the beta-chain of the high-affinity immunoglobulin E receptor (FcepsilonR1beta) is associated with a susceptibility to aspirin-intolerant asthma. Clin Exp Allergy 2006;36:877-883.

19 American Thoracic Society: Proceedings of the ATS workshop on refractory asthma: current understanding, recommendations, and unanswered questions. Am J Respir Crit Care Med 2000;162:2341-2351.
20 Bachert C, Gevaert P, van Cauwenberge P: Staphylococcus aureus superantigens and airway disease. Curr Allergy Asthma Rep 2002; 2:252-258.

21 Fleischer B: Superantigens. APMIS 1994;102: 3-12.

22 Seiberling KA, Conley DB, Tripathi A, Grammer LC, Shuh L, Haines GK 3rd, Schleimer R, Kern RC: Superantigens and chronic rhinosinusitis: detection of staphylococcal exotoxins in nasal polyps. Laryngoscope 2005;115: 1580-1585.

23 Veler $\mathrm{H}, \mathrm{Hu}$ A, Fatma S, Grunstein JS, DeStephan CM, Campbell D, Orange JS, Grunstein MM: Superantigen presentation by airway smooth muscle to CD4+ T lymphocytes elicits reciprocal proasthmatic changes in airway function. J Immunol 2007;178: $3627-3636$

24 Herz U, Ruckert R, Wollenhaupt K, Tschernig T, Neuhaus-Steinmetz U, Pabst R, Renz H: Airway exposure to bacterial superantigen (SEB) induces lymphocyte-dependent airway inflammation associated with increased airway responsiveness - a model for non-allergic asthma. Eur J Immunol 1999;29:1021-1031.

25 Patou J, Gevaert P, Van Zele T, Holtappels G, van Cauwenberge P, Bachert C: Staphylococcus aureus enterotoxin B, protein A, and lipoteichoic acid stimulations in nasal polyps. J Allergy Clin Immunol 2008;121:110-115.

26 Huvenne W, Callebaut I, Plantinga M, Vanoirbeek JA, Krysko O, Bullens DM, Gevaert $P$, Van Cauwenberge $P$, Lambrecht $B N$, Ceuppens JL, Bachert C, Hellings PW: Staphylococcus aureus enterotoxin B facilitates allergic sensitization in experimental asthma. Clin Exp Allergy 2010;40:1079-1090.

27 Bachert C, Gevaert P, Holtappels G, Johansson SG, van Cauwenberge P: Total and specific IgE in nasal polyps is related to local eosinophilic inflammation. J Allergy Clin Immunol 2001;107:607-614.
28 Perez-Novo CA, Claeys C, Van Zele T, Holtapples G, Van Cauwenberge P, Bachert C: Eicosanoid metabolism and eosinophilic inflammation in nasal polyp patients with immune response to Staphylococcus aureus enterotoxins. Am J Rhinol 2006;20:456-460.

29 Rossi RE, Monasterolo G: Prevalence of serum IgE antibodies to the Staphylococcus aureus enterotoxins (SAE, SEB, SEC, SED, TSST-1) in patients with persistent allergic rhinitis. Int Arch Allergy Immunol 2004;133: 261-266.

30 Barnes PJ: Intrinsic asthma: not so different from allergic asthma but driven by superantigens? Clin Exp Allergy 2009;39:1145-1151.

31 Huvenne W, Callebaut I, Reekmans K, Hens G, Bobic S, Jorissen M, Bullens DM, Ceuppens JL, Bachert C, Hellings PW: Staphylococcus aureus enterotoxin B augments granulocyte migration and survival via airway epithelial cell activation. Allergy 2010;65:1013-1020.

- 32 Cowburn AS, Sladek K, Soja J, Adamek L, Nizankowska E, Szczeklik A, Lam BK, Penrose JF, Austen FK, Holgate ST, Sampson AP: Overexpression of leukotriene $\mathrm{C} 4$ synthase in bronchial biopsies from patients with aspirinintolerant asthma. J Clin Invest 1998;101: 834-846.

33 Choi JH, Lee KW, Oh HB, Lee KJ, Suh YJ, Park CS, Park HS: HLA association in aspirinintolerant asthma: DPB1*0301 as a strong marker in a Korean population. J Allergy Clin Immunol 2004;113:562-564.

34 Dekker JW, Nizankowska E, SchmitzSchumann M, Pile K, Bochenek G, Dyczek A, Cookson WO, Szczeklik A: Aspirin-induced asthma and HLA-DRB1 and HLA-DPB1 genotypes. Clin Exp Allergy 1997;27:574-577.

35 Lee HY, Lee JW, Lee KW, Park MH, Park HS: The HLA allele marker for differentiating ASA hypersensitivity phenotypes. Allergy 2009;64:1385-1387. 